\title{
First evidence of Panulirus argus Virus 1 (PaV1) in spiny lobster from Cuba and clinical estimation of its prevalence
}

\author{
Yanis Cruz Quintana1,2,*, Rossanna Rodríguez Canul2, Víctor M. Vidal Martínez ${ }^{2,3}$ \\ ${ }^{1}$ Laboratorio de Sanidad Acuícola, Centro de Investigaciones Pesqueras, $5^{\text {ta }}$ ave y 246, Barlovento, Playa, \\ Ciudad de La Habana, Cuba \\ ${ }^{2}$ Laboratorios de Parasitología e Inmunología y Biología Molecular, Centro de Investigación y de Estudios Avanzados del \\ Instituto Politécnico Nacional, Unidad Mérida, Km 6 Carretera Antigua a Progreso, Cordemex, Mérida, Yucatán 97310, Mexico \\ ${ }^{3}$ Department of Ecology, Evolution and Marine Biology and Marine Science Institute, University of California, \\ Santa Barbara, California 93106, USA
}

\begin{abstract}
The present study documents the first finding of Panulirus argus Virus 1 (PaV1) in spiny lobster Panulirus argus from Cuba. Samples originated from 2 nursery sites, Matías Keys and Bocas de Alonso Keys, and 2 fishing sites, La Grifa and El Ramajo. Lobsters from the nursery sites (artificial reefs) were collected by SCUBA diving, while those from the fishing sites were collected from artificial shelters known as 'casitas cubanas'. In these shelters it was observed that healthy lobsters tended to avoid infected lobsters. Prevalence of PaV1 in the sampling sites was assessed by using clinical signs such as lethargy, an opaque reddish shell coloration, and milky white hemolymph with loss of clotting activity. The presence of PaV1 was subsequently confirmed by histology and PCR of tissues and hemolymph samples from suspected individuals. Histological sections of the hepatopancreas, gills, gonads, and gut showed infected hemocytes with hypertrophied nuclei and eosinophilic intranuclear Cowdry type A inclusions. A 499 bp band was observed by PCR. The sequence of the amplified fragments was $96 \%$ similar to the PaV1 sequence in GenBank. The overall mean prevalence of PaV1 was $4.48 \%$ (range: 0 to $9.3 \%$ ) after pooling the results of the 4 sampling sites.
\end{abstract}

KEY WORDS: Crustacea · Spiny lobster · Virus · Panulirus argus Virus $1 \cdot$ PaV1 $\cdot$ Cuba $\cdot$ Prevalence

\section{INTRODUCTION}

The spiny lobster Panulirus argus (Latreille, 1804) is the most important fishery resource of Cuba (Baisre \& Cruz 1994), generating approximately USD 70 million $\mathrm{yr}^{-1}$ (Puga 2005). There are 4 main fishing areas in Cuba, and the Batabano Gulf alone contributes up to $60 \%$ of the total catch (Adams et al. 2000). Previous studies of spiny lobsters in Cuba have focused on the biology (de León 2005) and catch predictions for this species (mainly in the Batabano Gulf) (Joyce 1997), but little was known about the presence and types of infectious diseases affecting $P$. argus. In 1999 a new lethal virus was discovered in juvenile $P$. argus from the
Florida Keys, Florida, USA (Shields \& Behringer 2004). This virus, Panulirus argus Virus 1 (PaV1), has also been reported in juveniles in Belize, the US Virgin Islands (Butler et al. 2008), and the Mexican Caribbean Sea (Huchin-Mian et al. 2008). Although PaV1 has not been fully characterized (Montgomery-Fullerton et al. 2007), it is known that it infects circulating hyalinocytes and semigranulocytes, and that heavily infected cells can be identified by eosinophilic intranuclear Cowdry type A inclusions (Shields \& Behringer 2004). Apart from hemocytes, spongy connective tissue is also a target tissue of this virus, with the hepatopancreas being the most severely affected organ (Huchin-Mian et al. 2008). Diseased lobsters become lethargic and 
have milky white hemolymph that does not clot. Molting is suppressed, the disease is irreversible, and the virus eventually kills the lobster during the late phase of infection (Shields \& Behringer 2004, Huchin-Mian et al. 2008).

There is concern about the actual geographical distribution of PaV1 through the Caribbean Sea because only scattered reports exist (Butler et al. 2008). Furthermore, the true prevalence of the disease within the Caribbean Sea is unknown, although PaV1 prevalence findings of $8 \%$ and $10.9 \%$ have been reported from the Florida Keys and the Mexican Caribbean, respectively (Shields \& Behringer 2004, Lozano-Álvarez et al. 2008).

As the export of live and frozen spiny lobsters (Hunt 2000, FAO 2001, 2004) is a significant source of revenue for the country (Adams 1998, Puga 2005), it is important to know if PaV1 is present in Cuba and the potential economic impact. It is also necessary to estimate its prevalence and distribution and identify geographical regions that are free of the disease. This information is critical to our understanding of the mechanisms of viral transmission and, thus, for implementing an efficient and effective management program. Therefore, the objective of the present study was to document, for the first time, the presence of PaV1 in Panulirus argus in Cuban waters using clinical signs, histology, and PCR. Additionally, by measuring the prevalence of this virus in different fishing areas, we identified areas that are currently disease-free.

\section{MATERIALS AND METHODS}

Sample collection. Spiny lobsters were collected by SCUBA diving in 4 sites located within the Batabano Gulf (Fig. 1). The Matías Keys $\left(21^{\circ} 33^{\prime} \mathrm{N}, 82^{\circ} 26^{\prime} \mathrm{W}\right)$ (Site 1$)$ and Bocas de Alonso Keys $\left(21^{\circ} 41^{\prime}\right.$ N, $82^{\circ} 28^{\prime} \mathrm{W}$ ) (Site 2) are nursery habitats of juvenile spiny lobsters (de León et al. 1991). La Grifa $\left(22^{\circ} 13^{\prime} \mathrm{N}, 82^{\circ} 47^{\prime} \mathrm{W}\right)$ (Site 3 ) and El Ramajo (22 $19^{\prime} \mathrm{N}, 83^{\circ} 03^{\prime} \mathrm{W}$ ) (Site 4 ) are fishing sites located near the nursery habitats of the juvenile lobsters (Fig. 1). In the nursery habitats (Sites 1 and 2), we sampled 10 artificial reefs made of $1.4 \mathrm{~m}^{2}$ concrete blocks placed in a linear row and located $25 \mathrm{~m}$ apart from each other. At each of the fishing sites (Sites 3 and 4), 30 to 100 artificial shelters of $1.5 \mathrm{~m}^{2}$ each, known as 'casitas cubanas', were sampled. This sampling strategy to compare PaV1 prevalence among lobsters from natural and artificial shelters was previously validated by Lozano-Álvarez et al. (2008) in the Mexican Caribbean Sea and no significant differences were found between sites. Thus, our sample strategy is comparable with the methodology of Lozano-Álvarez et al. (2008) and with Shields \& Behringer (2004), who collected organisms either from their natural habitats and/or artificial shelters. This method allows collecting of both healthy and sick lobsters from a given area and also produces differential sampling of the size classes, a characteristic typical of exploited populations. This is important because the advantage of collecting from

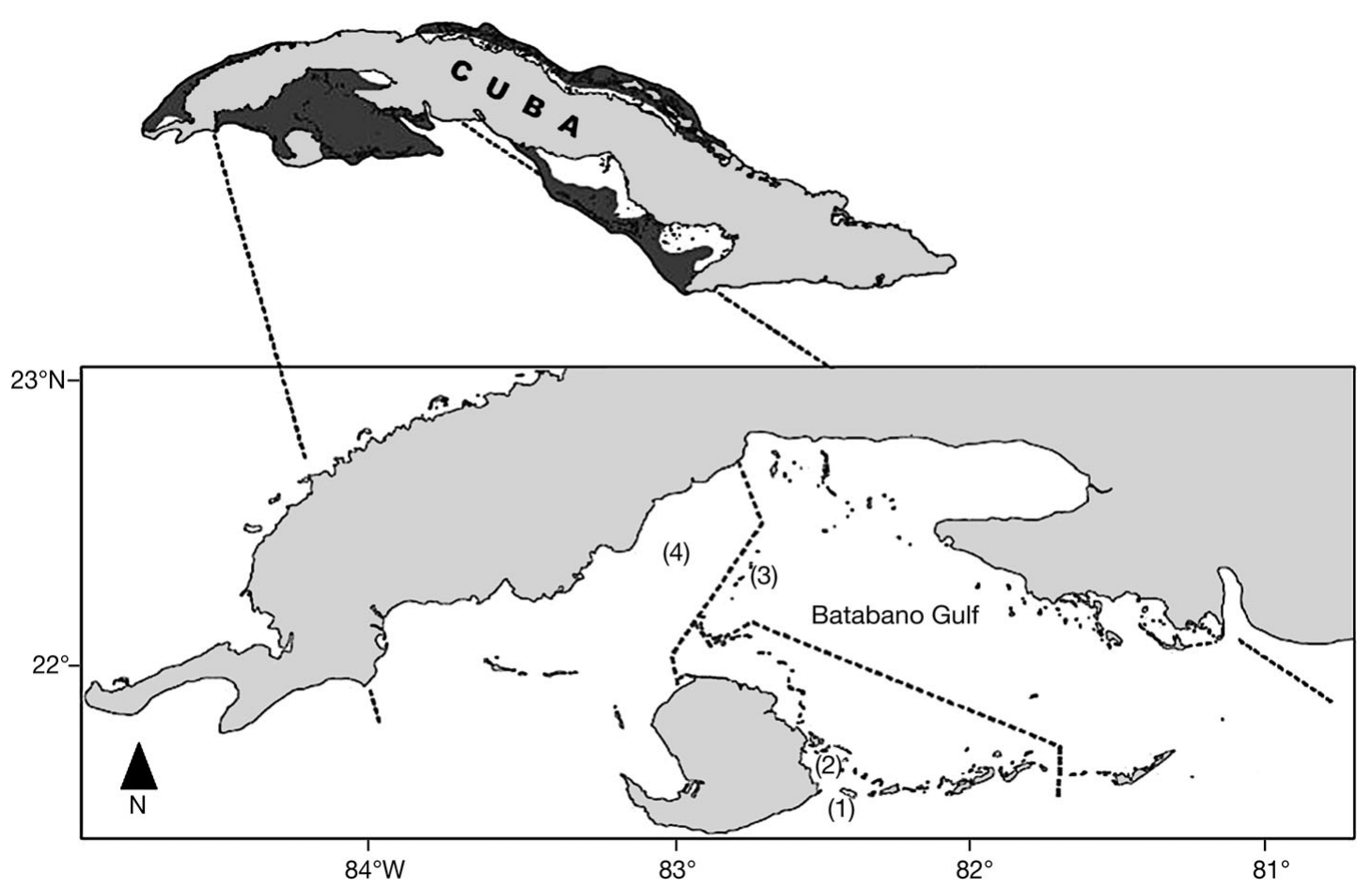

Fig. 1. Study sites in the Batabano Gulf, Cuba. Dark grey offshore shading in Cuba map indicates the 4 lobster fishing areas. Nursery sites: 1: Matías Keys; 2: Bocas de Alonso Keys. Fishing sites: 3: La Grifa; 4: El Ramajo 
the artificial shelters is that it permits determination of the prevalence of PaV1 in both juveniles and adults, depending on the habitat where the casitas cubanas are located.

The sampling was carried out twice annually during the dry (November 2003 to February 2004) and rainy seasons (June and July 2004). At each site, lobsters were measured (cephalothorax length [CL], in $\mathrm{mm}$ ) and externally inspected to diagnose PaV1 infection. Diagnosis was based on clinical signs according to Shields \& Behringer (2004): a reddish cuticle, lethargy, and white hemolymph visible through the thin membrane between the cephalothorax and abdomen. Disease prevalence was calculated, similar to LozanoÁlvarez et al. (2008) as the percentage of individuals in a sample that showed clinical signs of PaV1. Thus, to calculate the overall prevalence for all 4 sites, we pooled gregarious juveniles, sub-adults, and adults.

Histology. During fieldwork, the hepatopancreas, gills, heart, antennal gland, gonads, muscle, and gut fragments of the 156 lobsters that showed clinical signs were fixed in $10 \%$ neutral formalin for histological analysis. These samples were processed first at the Centro de Investigaciones Pesqueras de Cuba (CIP). Organs of 11 of these formalin-preserved lobsters were later processed at CINVESTAV-IPN Unidad Mérida using routine histological methods, producing $5 \mu \mathrm{m} \mathrm{sec-}$ tions that were then stained with Harris hematoxylin and eosin (H\&E) (Humason 1979, Lightner 1996).

PCR. During the collecting trip, hemolymph samples of 7 of the 11 juvenile spiny lobsters that were fixed for histology and processed at CINVESTAV-IPN Unidad Mérida were preserved in $96 \%$ ethanol (0.5 hemolymph:1 ethanol) for PCR confirmation.

DNA from the hemolymph $(\mathrm{n}=5)$ was extracted with $300 \mu \mathrm{l}$ of $10 \%$ Chelex 100 and $20 \mu \mathrm{l}$ of Proteinase K $\left(10 \mathrm{mg} \mathrm{ml}^{-1}\right)$ and incubated for $2 \mathrm{~h}$ at $55^{\circ} \mathrm{C}$. Then, samples were centrifuged at $11000 \times g$ for 5 min using a SIGMA 1-13 centrifuge, and the DNA-containing supernatant was collected. We used primers specific for PaV1, 45aF (5'-TTC CAG CCC AGG TAC GTA TC-3') and 543aR (5'-AAC AGA TTT TCC AGC AGC GT-3') (GenBank accession no. EF206313), to amplify a 499 bp region following a modified protocol of MontgomeryFullerton et al. (2007). All PCR reactions were carried out in a total volume of $25 \mu \mathrm{l}$ and contained $\sim 49.5 \mathrm{ng}$ DNA, $0.33 \mu \mathrm{M}$ of each primer, $2.5 \mathrm{mM} \mathrm{MgCl}_{2} 1.2 \times$ reaction buffer (50 mM KCl, 10 mM Tris- $\mathrm{HCl}, \mathrm{pH}$ 9.0, $0.1 \%$ Triton X-100), $0.4 \mathrm{mM}$ dNTP mixture (Promega), and $2.5 \mathrm{U}$ of Taq DNA polymerase (Promega). Using a thermal cycler (TECHNE TC-312), the reactions were incubated at $94^{\circ} \mathrm{C}$ for $10 \mathrm{~min}$, followed by 30 cycles of $94^{\circ} \mathrm{C}$ for $30 \mathrm{~s}, 63^{\circ} \mathrm{C}$ for $30 \mathrm{~s}$, and $72^{\circ} \mathrm{C}$ for $1 \mathrm{~min}$, with a final extension of $10 \mathrm{~min}$. The PCR products were run on $2 \%$ agarose gels and stained with $0.1 \%$ ethidium bromide.
UV photodocumentation (MiniBIS) was used to visualize the PCR products. DNA from the hemolymph of clinically confirmed diseased lobsters collected in Puerto Morelos, Quintana Roo, Mexico was used as a positive control (Huchin-Mian et al. 2008), whereas sterile water and tissue from non-infected lobsters were used as negative controls. The amplified PCR products were purified with a NOVAGEN DNA Purification Kit using a refrigerated ultracentrifuge (HERAEUS). The DNA concentration of all the PCR products was measured using a BioMate 3 UV spectrophotometer, and the amplified fragment was sequenced bi-directionally and compared with the sequence of PaV1 (GenBank accession no. EF206313) (Montgomery-Fullerton et al. 2007). Similarities in the consensus sequence were searched in GenBank using the basic local alignment search tool (BLAST; http://blast.ncbi.nlm.nih.gov/ Blast.cgi).

\section{RESULTS}

A total of 3481 Panulirus argus were collected in the Batabano Gulf from the 4 sampling sites during the dry $(n=1255)$ and rainy seasons $(n=2226)$ (Fig. 1$)$. They were classified as early benthic juveniles (38 to $50 \mathrm{~mm}$ cephalothorax length [CL]), sub-adults (51 to $79 \mathrm{~mm}$ CL), and adults ( $\geq 80 \mathrm{~mm} \mathrm{CL}$ ). A total of 156 lobsters $(4.48 \%)$ showed clinical signs of PaV1 infection characterized by lethargy, an opaque reddish shell coloration, and milky whitish hemolymph that lacked clotting activity. During sampling, lobsters with more evident clinical signs of infection were observed to be alone in the shelters (casitas cubanas) (data not shown). At necropsy, it was noticed that all suspected infected lobsters had an empty digestive tract.

\section{Dry season}

Of the 1255 lobsters surveyed, there were 245 juveniles, 661 sub-adults, and 349 adults. In February, the La Grifa and El Ramajo fishing sites were not surveyed because the lobster fishing season was officially closed. Only 3 lobsters with clinical signs of PaV1 were collected from La Grifa, 1 sub-adult and 2 adults, with a prevalence of 0.47 and $1.30 \%$, respectively (Table 1 ). No juveniles from the nursery sites at Matías or Bocas de Alonso Keys displayed symptoms of infection.

\section{Rainy season}

From the 2226 spiny lobsters collected, 179 were juveniles, 1657 were sub-adults, and 390 were adults. 
Table 1. Panulirus argus. Prevalence of Panulirus argus Virus 1 (PaV1) in spiny lobsters from the Batabano Gulf. J: early benthic juveniles; $\mathrm{S}$ : sub-adults; A: adults. nd: no data

\begin{tabular}{|c|c|c|c|c|c|c|c|c|c|c|c|c|}
\hline Stage & $\begin{array}{c}\mathrm{N} \\
\text { Total } \\
(\mathrm{N})\end{array}$ & $\begin{array}{l}\text { Jovember } \\
\text { Infected } \\
\text { (n) }\end{array}$ & $\begin{array}{l}2003 \\
\text { Prevalence } \\
\qquad(\%)\end{array}$ & $\begin{array}{c}\text { Total } \\
(\mathrm{N})\end{array}$ & $\begin{array}{l}\text { February } \\
\text { Infected } \\
\text { (n) }\end{array}$ & $\begin{array}{l}2004 \\
\text { Prevalence } \\
\qquad(\%)\end{array}$ & $\begin{array}{l}\text { Total } \\
(\mathrm{N})\end{array}$ & $\begin{array}{l}\text { June } 20 \\
\text { Infected } \\
\text { (n) }\end{array}$ & $\begin{array}{l}\text { Prevalence } \\
\qquad(\%)\end{array}$ & $\begin{array}{l}\text { Total } \\
(\mathrm{N})\end{array}$ & $\begin{array}{l}\text { July } 2004 \\
\text { Infected } \\
\text { (n) }\end{array}$ & $\begin{array}{l}4 \\
\text { Prevalence } \\
\quad(\%)\end{array}$ \\
\hline \multicolumn{13}{|c|}{ Matías Keys } \\
\hline $\mathrm{J}$ & 9 & 0 & 0 & 12 & 0 & 0 & 2 & 0 & 0 & 4 & 0 & 0 \\
\hline $\mathrm{S}$ & 5 & 0 & 0 & 2 & 0 & 0 & 7 & 0 & 0 & 8 & 0 & 0 \\
\hline \multicolumn{13}{|c|}{ Bocas de Alonso Keys } \\
\hline $\mathrm{J}$ & 126 & 0 & 0 & 98 & 0 & 0 & 43 & 0 & 0 & 94 & 0 & 0 \\
\hline $\mathrm{S}$ & 80 & 0 & 0 & 255 & 0 & 0 & 138 & 0 & 0 & 103 & 0 & 0 \\
\hline \multicolumn{13}{|c|}{ La Grifa } \\
\hline $\mathrm{J}$ & nd & nd & nd & nd & nd & nd & 16 & 7 & 43.75 & 9 & 4 & 44.44 \\
\hline S & 214 & 1 & 0.47 & nd & nd & nd & 409 & 37 & 9.05 & 294 & 27 & 9.18 \\
\hline A & 157 & 2 & 1.30 & nd & nd & nd & 91 & 3 & 3.30 & 120 & 1 & 0.83 \\
\hline \multicolumn{13}{|c|}{ El Ramajo } \\
\hline J & nd & nd & nd & nd & nd & nd & 9 & 4 & 44.44 & 2 & 0 & 0 \\
\hline S & 105 & 0 & 0 & nd & nd & nd & 396 & 32 & 8.08 & 302 & 37 & 12.25 \\
\hline A & 192 & 0 & 0 & nd & nd & nd & 77 & 0 & 0 & 102 & 1 & 0.98 \\
\hline
\end{tabular}

Table 2. Panulirus argus. Clinical signs and histological lesions produced by Panulirus argus Virus 1 (PaV1) in lobsters from the Batabano Gulf

\begin{tabular}{|c|c|c|}
\hline Clinical signs & Histological lesions & Lobsters (n) \\
\hline Milky white hemolymph & $\begin{array}{l}\text { Moderate hemocytic infiltrate } \\
\text { Some fixed phagocytes infected }\end{array}$ & 17 \\
\hline $\begin{array}{l}\text { Milky white hemolymph } \\
\text { Low-grade lethargy } \\
\text { Alone in the shelter }\end{array}$ & $\begin{array}{l}\text { Atrophy of hepatopancreas } \\
\text { Moderate obstruction of hemal } \\
\text { sinuses by hemocytic infiltration } \\
\text { Moderate no. of infected cells } \\
\text { in other tissues }\end{array}$ & 85 \\
\hline $\begin{array}{l}\text { Milky white hemolymph } \\
\text { Reddish cuticle } \\
\text { Severe lethargy } \\
\text { Alone in the shelter }\end{array}$ & $\begin{array}{l}\text { Atrophy of hepatopancreas } \\
\text { Severe obstruction of hemal } \\
\text { sinuses by hemocytic infiltrates } \\
\text { Scarce or null reserve inclusions } \\
\text { Pyknotic cells in connective tissue } \\
\text { Many infected cells in other tissues }\end{array}$ & S \\
\hline
\end{tabular}

A total of 153 lobsters (6.87\%) showing clinical signs of PaV1 were collected from the fishing sites at La Grifa and El Ramajo (15 juveniles, 133 sub-adults, and 5 adults), with prevalences ranging from 0.83 to $44.44 \%$ (Table 1).

It was not possible to compare the dry season with the rainy season results due to the sampling problem during the former. Thus, for descriptive purposes only, all of the sampled lobsters for a given season were pooled (juveniles, sub-adults, and adults) and the disease prevalence was determined to be $6.87 \%$ for the rainy season and $0.23 \%$ for the dry season. At the nursery sites, no lobsters demonstrated clinical signs of PaV1 infection, but at the fishing sites, the overall prevalence was $6.25 \%$. Early benthic juveniles showed a higher prevalence $(41.66 \%)$ than sub-adults $(4.95 \%)$ and adults $(0.95 \%)$. The overall prevalence of PaV1 in the 4 sampling sites was $4.48 \%$.

\section{Histology}

The infected lobsters showed hypertrophied nuclei with condensed and emarginated chromatin in hyalinocytes and semigranulocytes. Similar to the findings of Shields \& Behringer (2004), the granulocytes were not affected. Intranuclear eosinophilic Cowdry type A inclusion bodies at different stages of development were also observed. In 17 of 156 lobsters (10.89\%), a moderate amount of hemocytic infiltrate was observed together with some fixed infected phagocytes (Table 2). In 139 of 156 lobsters (89.10\%), the hepatopancreatic tubules showed signs of atrophy together with an increase in infected hemocytes and fixed phagocytes in the connective tissue surrounding the hemal sinuses. Some of these lobsters (54 of 139) also demonstrated pyknotic nuclei within the spongy connective tissue of the hepatopancreas, and hemocytic infiltrates appeared to occlude the hemal sinuses. Infected cells were abundant in the gut, antennal gland, gills, and hepatopancreatic tissue and less frequent in the muscle and heart tissue. Individuals with higher levels of infection (54 of 156 lobsters) had little or no lipid reserves within the $\mathrm{R}$ cells of the hepatopancre- 
atic tubules and the connective tissues. Additionally, 7 female lobsters showed abundant hemocytic infiltrates and Cowdry type A inclusion bodies in their gonads. Five of them, representing $1.5 \%$ of the 331 adult females surveyed, were heavily infected with PaV1, demonstrating 10 or more Cowdry type A inclusion bodies per field. Using the Cowdry type A inclusion body severity grade scale of 0 to 4 recommended by Lightner (1996) for grading penaeid shrimp infections caused by the infectious hypodermal and hematopoietic necrosis virus (IHHNV), these lobsters were determined to have grade 4 (highest severity) infections. The oocyte nodules were separated by infiltrating infected hemocytes and, in some cases, these infiltrates were observed around each ovocyte at different stages of maturation (Figs. 2 \& 3). However, histologically, the oocytes themselves did not appear to be infected.

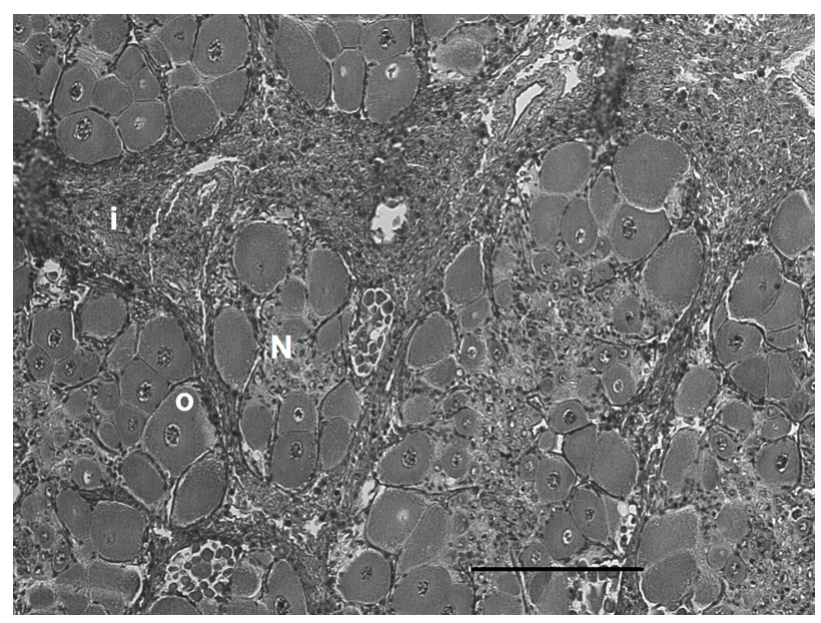

Fig. 2. Panulirus argus. Gonad from a diseased spiny lobster. $\mathrm{N}$ : oocyte nodule; o: ovocyte; i: hemocytic infiltrate. Scale bar $=250 \mu \mathrm{m}$

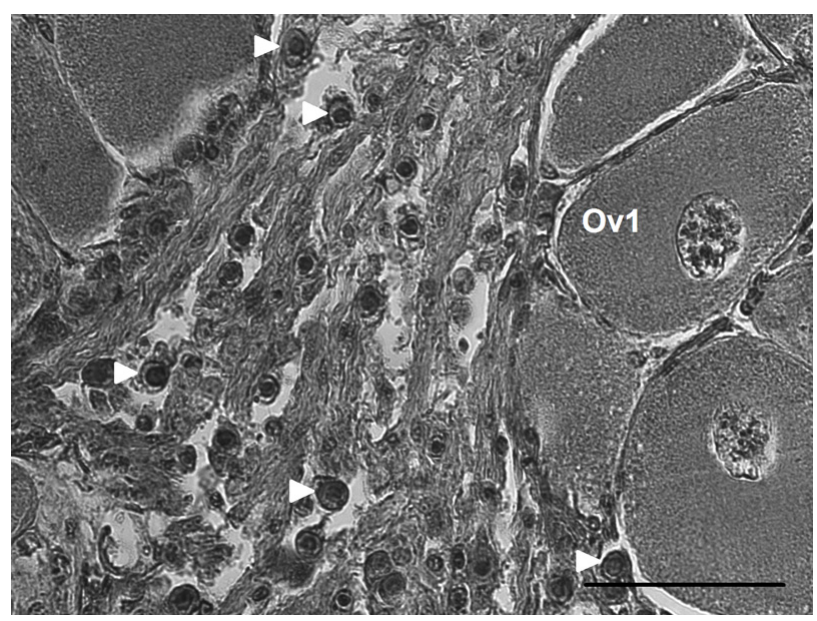

Fig. 3. Panulirus argus. Gonad from a diseased spiny lobster. Ov1: ovocyte 1. Infected cells show Cowdry type A inclusions (arrowhead). Scale bar $=100 \mu \mathrm{m}$

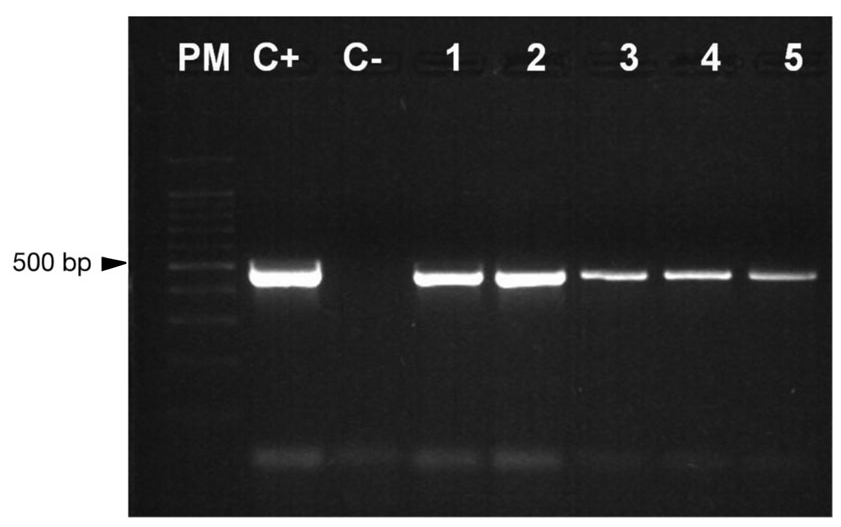

Fig. 4. Panulirus argus. PCR analysis of 5 diseased lobsters from the Batabano Gulf. PM: $100 \mathrm{bp}$ ladder; C+: positive control corresponding to Panulirus argus Virus 1 (PaV1) DNA extracted from a diseased lobster from Puerto Morelos; $\mathrm{C}-$ : negative control reaction with distilled water; 1 to 5 : $P$. argus hemolymph samples. Band intensity is related to DNA concentration

PCR

Only 5 of the 7 samples were useful for DNA extraction. This might be because hemolymph fixed in ethanol is unstable after long periods of storage due to oxidation. In this case, the samples were processed after $5 \mathrm{yr}$ of ethanol fixation. Furthermore, exposure of the samples to high ambient temperatures during the field trip may have contributed to their degradation. A $499 \mathrm{bp}$ amplification product was observed in the 5 samples analyzed (Fig. 4). This corresponded to the specific region of PaV1 previously reported by Montgomery-Fullerton et al. (2007). The DNA sequence of the PCR products was $96 \%$ similar to the sequence of PaV1 from Florida (GenBank accession no. EF206313) (Montgomery-Fullerton et al. 2007). Further sequencing and more comparisons will be necessary to determine if the Cuban PaV1 represents a geographical variant of PaV1.

\section{DISCUSSION}

The clinical, histological, and molecular results from the present study support the view that the etiological agent found infecting the spiny lobster in Cuba is PaV1. This virus was first discovered in 1999 in juvenile lobsters from Florida (Shields \& Behringer 2004), and was also found in the Mexican Caribbean Sea (Huchin-Mian et al. 2008), Belize, and the US Virgin Islands (Butler et al. 2008). Furthermore, it has also been suggested that the virus has spread throughout the Caribbean Sea (Butler et al. 2008). 
There are 3 novel findings stemming from the present study. First, the prevalence results are from a commercial fishery, although our methodology of catching based on artificial shelters (casitas cubanas) is similar to some other studies. Second, no other study has presented data on the prevalence of PaV1 in adult lobsters, and the present findings clearly extend our knowledge of the epizootiology of this virus. Third, we found histological evidence of the virus within infected hemocytic infiltrates located between the oocyte nodules, but not inside the oocytes themselves.

The overall prevalence of PaV1 in the 4 sample sites from the Batabano Gulf $(4.48 \%)$ was lower than that reported by Shields \& Behringer (2004) from the Florida Keys (6 to $8 \%$ ) and Lozano-Álvarez et al. (2008) from the Mexican Caribbean Sea (10.9\%). It is likely that the difference in PaV1 prevalence values between those studies and ours is because our data was obtained from fishing sites where adult and sub-adult lobsters are more abundant rather than juveniles. For example, our specimens had a CL range between 38 and 93 mm, while those of Lozano-Álvarez et al. (2008) were between 11 and $89 \mathrm{~mm}$. PaV1 is more prevalent in small juvenile lobsters (CL: 11 to $37 \mathrm{~mm}$ ) (Shields \& Behringer 2004, Butler et al. 2008) and our lack of data for this size class could explain our lower prevalence. Even with the low prevalence values, it is important to mention that our results were obtained from industrial commercial fisheries. These are baseline values for fisheries department officials to consider in developing new policies that address the diseased-lobster issue. Currently, the common practice of Cuban fishers is to separate diseased from healthy lobsters and discard the former on shore to minimize disease spread. Additionally, since we had no access to the areas with the highest prevalence of PaV1 during the dry season, it is virtually impossible to make a reliable comparison of seasonal data. In fact, it is clear that the higher prevalence of the disease in the rainy season $(6.87 \%)$ compared to the dry season $(0.23 \%)$ may be a product of sampling bias. Since samples can only be obtained during the normal Cuban lobster-fishing season, it will be necessary for future investigators to obtain permission to sample throughout the year in order to obtain a clear picture of possible seasonal differences in disease-prevalence values.

As in the present study, Shields \& Behringer (2004) and Lozano-Álvarez et al. (2008) determined prevalence using clinical signs, a method that can generate a large number of false negatives due to its low sensitivity when compared with histology and PCR. Animals with low levels of infection and without clinical symptoms of PaV1 infection are not detected using this method. We suggest using this method along with other techniques such as PCR or biopsy, in conjunction with fast molecular techniques, such as loop-mediated isothermal amplification (LAMP), to obtain a more accurate estimate of disease prevalence.

The data in Table 1 suggests that the prevalence of $\mathrm{PaV} 1$ is higher in juveniles than in sub-adults and adults (considering that the present survey is the first to include a large number of adult lobsters). Due to the characteristics of the sampling program, which was dependent upon fishing-boat schedules, the number of juveniles examined was lower than that of sub-adults and adults (Table 1). However, the prevalence values for the juveniles collected from La Grifa and El Ramajo between June and July were high. In fact, adding together the juveniles collected during these 2 mo gives a total of 36 juveniles with an overall disease prevalence of $41.66 \%$. Likewise, it is unclear if this prevalence value is seasonal, as we were unable to collect juveniles from these 2 localities during the November and February samplings and no infected juveniles were collected from Matías or Bocas de Alonso Keys during these same sampling periods (Table 1). Field and laboratory observations suggest that the prevalence of detectable PaV1 infection declines with increasing lobster size (Behringer 2003) and is nearly undetectable $(<1 \%)$ among adults (Shields \& Behringer 2004). Our findings support this conclusion (Table 1).

The infection pattern of PaV1 in the Cuban lobsters was similar to previously observed patterns in other countries (Shields \& Behringer 2004, Huchin-Mian et al. 2008, Li et al. 2008). PaV1 shows characteristics of a systemic disease affecting the majority of the organs in its advanced stages. The widespread lesion distribution facilitates the diagnosis of severe infection, but the preference of PaV1 for fixed phagocytes within the hepatopancreas (Li et al. 2008) may also be useful for the diagnosis of low-level infection.

One of the most striking findings of the present study is that the gonads of adult females were heavily infected with PaV1, not only suggesting the possibility of vertical transmission of $\mathrm{PaV1}$, but also raising the question of why juveniles appear to be more susceptible to infection than adults (Shields \& Behringer 2004, Huchin-Mian et al. 2008). Experimental transmission of the virus by inoculation, ingestion, and cohabitation has been accomplished under laboratory conditions (Butler et al. 2008), but vertical transmission has not been considered as a possible route of infection until now. Vertical transmission from adult to offspring has been reported for IHHNV and white spot syndrome virus (WSSV) in penaeid shrimp (Lightner 1996). In the present study, no infected oocytes were detected by routine histology, but additional analyses using more sensitive diagnostic methods, such as in situ hybridization, are needed to determine if the oocytes are infected with PaV1. 
Due to the importance of the lobster fishery to Cuba and other Caribbean countries, we feel there is an urgent need to establish a permanent program to monitor the prevalence of this virus over time in the Caribbean. This is based on the premise that there is a possible link between global climate change (GCC) and a reported increase in diseases among marine organisms (Harvell et al. 2002, 2004, Ward \& Lafferty 2004). Whether GCC or some other factors are somehow enhancing the dispersion of PaV1 among Panulirus argus populations are questions that remain to be answered in order to develop strategies to protect this valuable fishery resource.

Acknowledgements. We thank CONACyT for providing a postgraduate scholarship to Y.C.Q. (Grant 215808). This paper is part of the PhD thesis of Y.C.Q. Financial support was from a SEP-PROMEP award, 'Propuesta sobre Calentamiento Global y Cambio Climatico de la Red Académica de Instituciones SEP-PROMEP del Sureste: área Sensibilidad Marina' and a FOMIX Yucatán award, 'Sensibilidad y vulnerabilidad de los ecosistemas costeros del sureste de México ante el Cambio Climático Global'. This document is an output from the British Council Mexico Research Links Project funded by the British Council for the benefit of the Mexican Higher Education Sector and the UK Higher Education Sector. The views expressed are not necessarily those of the British Council. Special thanks to R. Silveira Coffigny, O. García-Morel, N. González-Herrasti, J. P. Huchin-Mian, J. A. Pérez-Vega, R. Simá-Álvarez, and G. Arjona-Torres for their invaluable technical support.

\section{LITERATURE CITED}

Adams CM (1998) An overview of the Cuban commercial fishing industry and implications to the Florida seafood industry of renewed trade. Doc no. IW98-3. International Agricultural Trade and Development Center, Food and Resource Economics Department, University of Florida, Gainesville, FL

Adams CM, Sanchez VP, García AA (2000) An overview of the Cuban commercial fishing industry and recent changes in management structure and objectives. EDIS document FE 218. Institute of Food and Agricultural Sciences, University of Florida, Gainesville, FL. Available at www.edis.ifas.ufl.edu

Baisre JA, Cruz R (1994) The Cuban spiny lobster fishery. In: Phillips BF, Cobb JS, Kittaka J (eds) Spiny lobster management. Fishing News Books, Oxford, p 119-132

Behringer DC (2003) The ecological ramifications of disease and density in the Caribbean spiny lobster Panulirus argus. PhD thesis, Old Dominion University, Norfolk, VA

Butler MJ, Behringer DC, Shields JD (2008) Transmission of Panulirus argus virus 1 (PaV1) and its effect on the survival of juvenile Caribbean spiny lobster. Dis Aquat Org 79:173-182

de León ME (2005) Variabilidad temporal de los parámetros poblacionales de la langosta espinosa del Caribe Pan- ulirus argus (Latreille, 1804) en aguas de Cuba. PhD thesis, CIBNOR, La Paz

de León ME, Cruz R, Díaz E, Brito R, Puga R, del Castillo J (1991) Distribución y estacionalidad de los juveniles de Panulirus argus en la plataforma Cubana. Rev Invest Mar 12:117-124

FAO (Food and Agriculture Organization) (2001) Report of the workshop on management of the Caribbean spiny lobster (Panulirus argus) fisheries in the area of the Western Central Atlantic Fishery Commission. Merida, Mexico, 4-8 Sep 2000. FAO Fish Rep No. 643. FAO, Rome

FAO (Food and Agriculture Organization) (2004) Fisheries global information system. Factsheet for Panulirus argus. Available at www.fao.org/figis/servlet/species?fid=3445

Harvell CD, Mitchell C, Ward J, Altizer S, Dobson AP, Ostfeld RS, Samuel MD (2002) Climate warming and disease risks for terrestrial and marine biota. Science 296:2158-2162

Harvell D, Aronson R, Baron N, Connell J and others (2004) The rising tide of ocean diseases: unsolved problems and research priorities. Front Ecol Environ 2:375-382

- Huchin-Mian JP, Rodríguez-Canul R, Arias-Bañuelos E, Simá-Álvarez R, Pérez-Vega JA, Briones-Fourzán $\mathrm{P}$, Lozano-Álvarez E (2008) Presence of Panulirus argus Virus 1 (PaV1) in juvenile spiny lobsters Panulirus argus from the Caribbean coast of Mexico. Dis Aquat Org 79: 153-156

Humason GL (1979) Animal tissue techniques, 4th edn. WH Freeman, San Francisco, CA

Hunt JH (2000) Status of the fishery for Panulirus argus in Florida. In: Phillips BF, Kittaka J (eds) Spiny lobsters: fisheries and culture, 2nd edn. Blackwell Scientific Press, Oxford, p 189-199

Joyce IT (1997) The spiny lobster fishery in Cuba. Geogr Rev 87:484-503

Li C, Shields JD, Ratzlaff RE, Butler MJ (2008) Pathology and haematology of the Caribbean spiny lobster experimentally infected with Panulirus argus virus 1 (PaV1). Virus Res 132:104-113

Lightner DV (1996) A handbook of pathology and diagnostic procedures for diseases penaeid shrimp. World Aquaculture Society, Baton Rouge, LA

Lozano-Álvarez E, Briones-Fourzán P, Ramírez-Estévez A, Placencia-Sánchez D, Huchin-Mian JP, Rodríguez-Canul R (2008) Prevalence of Panulirus argus Virus 1 (PaV1) and habitation patterns of healthy and diseased Caribbean spiny lobsters in shelter-limited habitats. Dis Aquat Org 80:95-104

> Montgomery-Fullerton MM, Cooper RA, Kauffman KM, Shields JD, Ratzlaff RE (2007) Detection of Panulirus argus Virus 1 in Caribbean spiny lobsters. Dis Aquat Org 76:1-6

Puga R (2005) Modelación bioeconómica y análisis de riesgo de la pesquería de langosta espinosa Panulirus argus (Latreille, 1804) en el Golfo de Batabanó, Cuba. PhD thesis, CIBNOR, La Paz

> Shields JD, Behringer DC Jr (2004) A new pathogenic virus in the Caribbean spiny lobster Panulirus argus from Florida Key. Dis Aquat Org 59:109-118

Ward JR, Lafferty K (2004) The elusive baseline of marine disease: are marine diseases in ocean ecosystems increasing? PLoS Biol 2:e120

Submitted: June 18, 2010; Accepted: August 30, 2010

Proofs received from author(s): December 3, 2010 